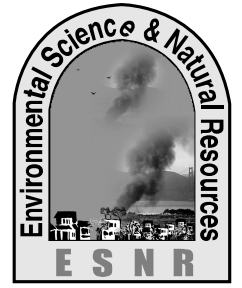

\title{
Analysis of the Proximate Composition of Domesticated Stock of Pangas (Pangasianodon hypophthalmus) in Laboratory Condition
}

\author{
M. Begum ${ }^{1}$, T. Akter ${ }^{1}$ and M. H. Minar ${ }^{2}$ \\ ${ }^{1}$ Fish Technology Research Section, Institute of Food Science and Technology, BCSIR, Dhaka \\ ${ }^{2}$ Department of Fisheries Biology and Genetics, Bangladesh Agriculture University, Mymensingh
}

\begin{abstract}
A study was undertaken to determine the proximate composition of aquarium reared pangus (Pangasianodon hypophthalmus) fish. Fresh aquarium pangas fish were used during the whole experiment and the fishes were under identical rearing conditions from fingerling till adult. The proximate biochemical composition of domesticated stock of raw pangas muscles were determined through determination of moisture, Protein, Fat and Ash of the edible portion. And the results indicates the moisture, protein, fat and ash percentage $(\%)$ were $78.29 \pm 0.22,12.78 \pm 0.16,16.55 \pm 1.52$ and $1.78 \pm 0.19$, respectively. Therefore, this fish can play a significant role to fulfill the nutrient demand of the people in Bangladesh.
\end{abstract}

Key words: Aquarium fish, Pangus, Proximate composition

\section{Introduction}

Bangladesh has the third largest aquatic fish biodiversity in Asia with about 800 species in fresh, brackish and marine water (Hussain and Mazid, 2001). The country has a total of 265 freshwater species and 475 marine species and 24 exotic species (DoF, 2010). Fisheries sector contributed about 3\% of the total export earning, $3.74 \%$ of GDP and $22.23 \%$ of agricultural sector in 2008-09 (DoF, 2010). Annual total fish production in 2008-09 in Bangladesh is about 2,701,370 MT (DoF, 2010). Fish also contributed about $58 \%$ to the nation's animal protein (DoF, 2010). At present annual fish intake by an individual is $17.52 \mathrm{~kg}$ and the annual fish demand is 29.74 metric tons (DoF, 2010). So it can reduce its malnutrition problem by increasing the production of fish.

Fish muscle comprises of moisture, protein and fat as a major nutrient components and carbohydrates, vitamins and minerals as minor components. So fish muscle contains all the nutrient components that is required most for human body maintenance. Fish and fish products are the most important sources of animal protein in the human diet. It comprises of all the ten essential amino acids in desirable quantity for human consumption. Fish protein is very rich in such amino acid as methionine, lysine and low in tryptophan compared to mammalian protein (Nowsad, 2007). Fish have rich source of essential nutrients required for supplementing both infant and adult diets (Abdullahi et al., 2001).

Fish normally has more poly unsaturated fatty acids than animal fats. Since their importance from medical point of view is obvious. An increasing amount of evidences suggest that due to its high content of polyunsaturated fatty acid fish flesh and fish oil are beneficial in reducing the serum cholesterol (Stansby, 1985).

Proximate composition generally comprises the estimation of moisture, protein, fat and ash contents of the fresh fish body. The percentage composition of these constituents accounts for about $96-98 \%$ of the total tissue constituents in fish (Nowsad, 2007). The assessment of the proximate composition of the fish is not only important to know its nutritive value, but also for its better processing and preservation (Mridha, 2005).

Due to increased demand for fish resources (fish being one of the major sources of protein), caused by the human population explosion, fish species capable of producing a higher biomass in a shorter period than native species were introduced. About 15 alien species of fish, mostly carps, were introduced to Bangladesh (Rahman, 1997).

Pangasianodon hypophthalmus is commonly known as pangas or iridescent shark in Bangladesh, belonging to the family pangasiidae, under the order Siluriformes. According to Roberts and Vidthayanon (1991) reported the origin of $P$. hypophthalmus was Siluriformes. According to Roberts and Vidthayanon (1991) the origin of $P$. hypophthalmus was from the Mekong river of Vietnam to the Chao Phraya River to Thailand from; subsequently it was spread over other countries such as Malaysia, Indonesia and China. According to David (1962) Pangasius sp. is highly tolerant to salinity, $\mathrm{pH}$, dissolved oxygen, temperature or even pollution. $P$. hypophthalmus is well accepted by a wide range of people and 
therefore, it has been a good source of protein and calorie. Poor, medium and better-off people in rural as well as urban areas. Their omnivorous diet consists of crustaceans, other fish, and plant matter (Axelrod, 1996).

Juvenile iridescent sharks are often sold as pets for home aquariums. However, they are not easy fish to keep, and are not recommended for home aquariums. Iridescent sharks are schooling fish that prefer to be kept in groups of five or more. If given enough room and feed adequately, an individual of this species can reach $1 \mathrm{~m}$ ( 3 feet) in length. In most home aquariums, the amount of space an iridescent shark has severely stunts its growth. For this reason, most iridescent sharks kept in home aquaria grow to only 15 to $30 \mathrm{~cm}$ (6 to 12 inches) in length and die prematurely from organ failure.

The processor, the nutritionist, the cook and the consumer all have a direct interest in the composition of fish. Proximate composition of fish varied widely from species to species and even within the same species from one individual to another. This individual variation is normally due to some factors such as size, age, season, sex and geographical location (Stansby, 1962.). The consumer is interested mainly in the edible part of the fish that is the flesh or muscle, the fish meal manufacturer is concerned with the composition of the whole fish. So, to know the composition of nutrients of the body of fish is very important for different users. Therefore, the aim of the present study was to determine the proximate composition of domesticated stock of pangus in laboratory condition.

\section{Materials and Methods}

The experimental fishes were collected from aquariums which were brought to the laboratory at fingerling stage in 2009. The average length of the fish at the time of experiment was 11 inch as they stayed in the aquarium which is not a suitable place for growing. The whole experiment was carried out at Fish Technology Research section of the Institute of Food Science and Technology (IFST) of Bangladesh Council of Scientific and Industrial Research (BCSIR), Dhanmondi, Dhaka during September to December, 2011.

\section{Preparation of the sample for test}

The sample was cut into very small pieces for test various examinations. Determination of moisture content of the raw fish was conducted by AOAC method (AOAC, 1975). The crude protein of the fish was determined by Micro- Kjeldhal method (Pearson, 1999). The estimation of fat content of experimental raw fish had been accomplished by Bligh and Dyer method (Bligh and Dryer, 1999). The fresh raw samples ( $2 / 3$ grams) were minced, weighed and ignited in the crucible. Then it was transferred in the Muffle Furnace held at dark red at a rate of $550^{\circ}$ $600^{\circ} \mathrm{C}$ for $6-8$ hours until the residue was white. Finally the percentage of ash content was calculated.

(a) Calculation of moisture :-

$$
\text { \%of moisture }=\frac{\text { Weight loss }}{\text { Original waight of the sample taken }} \times 100
$$

\section{(b) Calculation of protein :-}

The percentage of nitrogen I sample was calculated by the following formula-

$\%$ of $\mathrm{N}_{2}=($ Titration reading-blank reading $) \times$ Strength of Acid $\times 100 / 5 \times 100 /$ weight of the sample. For most routine purpose the $\%$ of protein in the sample is the calculated by multiplying the $\%$ of $\mathrm{N}_{2}$ with an empirical factor 6.25 for the fish.

$$
\% \text { of the protein }=\% \text { of total } \mathrm{N}_{2} \times 6.25
$$

(c) Calculation of fat :-

$$
\text { \%of fat }=\frac{\text { Weight of the regidue }}{\text { Weight of the sample taken }} \times 100
$$

(d) Calculation of ash :-

$$
\text { \%of ash }=\frac{\text { Weight of dry sample }}{\text { Original weight of the sample taken }} \times 100
$$


Statistical analysis: The data were collected from the experiment was tabulated and the final result was prepared by using both M.S Excel and SPSS 11.5 for windows.

\section{Results and Discussion}

The proximate composition of the studied fish found in the experiment has been shown in the table 1 and in figure 1.

Table 1. Proximate composition of Pangus.

\begin{tabular}{|c|c|c|c|c|}
\hline Number of Samples & Moisture & Protein & Fat & Ash \\
\hline 1 & 78.26 & 12.78 & 14.53 & 1.37 \\
\hline 2 & 78.47 & 12.94 & 18.54 & 1.89 \\
\hline 3 & 78.60 & 12.50 & 15.58 & 1.87 \\
\hline 4 & 77.90 & 13.00 & 17.89 & 1.83 \\
\hline 5 & 78.05 & 12.63 & 16.14 & 1.92 \\
\hline 6 & 78.36 & 12.58 & 15.90 & 1.85 \\
\hline 7 & 78.50 & 12.85 & 14.24 & 1.88 \\
\hline 8 & 78.40 & 12.69 & 18.03 & 1.56 \\
\hline 9 & 78.15 & 12.88 & 17.95 & 1.68 \\
\hline
\end{tabular}

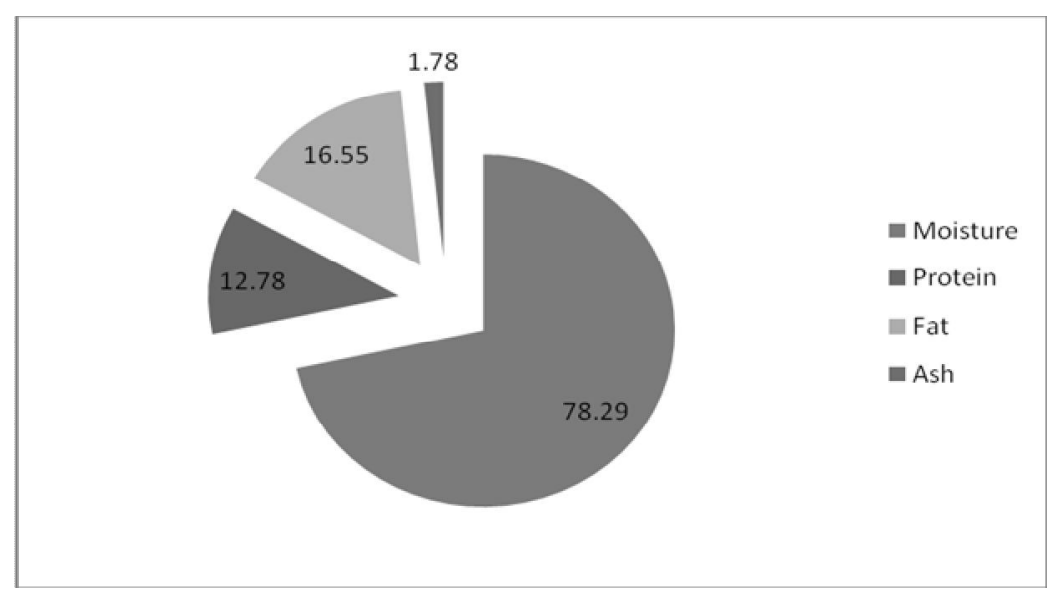

Fig. 1. Proximate composition of Pangasianodon hypophthalamu

\section{Moisture}

From the above results, the moisture percentage (\%) was found $78.29 \pm 0.22$. This results coincides with the findings of Nabi and Hossain (1989) in $M$. aculetus, Salam et al. (1995) in P.gonionotus and Mazumder et al. (2008) in A. mola, P. chola, G. chapra and in $P$. atherinoides. These findings also agreed with observation of Marias and Erasmus (1977) in several freshwater fish species. Usually moisture and lipid contents in fish fillets are inversely related and their sum is approximately 80\% (FAO, 1999).

\section{Protein}

The protein content $(\%)$ was $12.78 \pm 0.16$ which is more or less coincides with the findings of Mazumder et al. (2008) in G. chapra and P. chola. The results of protein percentage in Labeo rohita and L. calabasu of the research findings of Saha and Guha which were $16.6 \%$ and $14.7 \%$ respectively. Gheyasuddin et al. 
(1979) also found the result of protein percentage in silver pomfret (Stromateus cinereus) was $16.70 \%$ and Ribbon fish (Trichiurus haumela) was $16.6 \%$ while the percentage was much higher in $C$. gariepinus $19.64 \%$ and in Cirrhinus reba $19.74 \%$ found by Osibona (2006) and Mridha et al. (2005) respectively.

\section{Fat}

The fat content $(\%)$ was $16.55 \pm 1.52$. Saha and Guha (1939) on their study about 34 species estimated

highest amount of fat in Hilsha 19.4\%. The result is very much higher than some other commercial native fish to Bangladesh like Shoal (Channa striatus), Lata (Ophiocephalus punctatus) and Shingi (Heteropneustes fossilis) whose fat content was $0.64 \%, 1.08 \%$ and $1.23 \%$ respectively estimated by Qudrat-I-Khuda et al. (1962).

\section{Ash}

The ash content was $1.78 \pm 0.19$ which was nearer to the result of Abimbola (2010) in Tilapia guineensis and Tilapia melanotheron which contained $1.30 \%$ and $1.06 \%$ respectively. Mazumder et al. (2008) in A. coila and in A. mola also find similar ash percentage varied within $1.6 \%$ to $3.2 \%$. The ash content of the fish (O. rubicundus) was also more or less similar to that of small indigenous species. Chakwa and Shaba (2009) found higher amount of ash content in $C$. gariepinus $(3.06 \%)$ than the studied fish, while Devadsan et al. (1978) in his experiment found lower amount of ash content in six freshwater fishes $L$. rohita (1.31\%), Catla catla (0.93\%), Cirrihinus cirrhosus (1.40\%), L. calabasu (1.02\%), Mystus seeghala $(0.91 \%)$ and Wallagu attu $(0.72 \%)$.

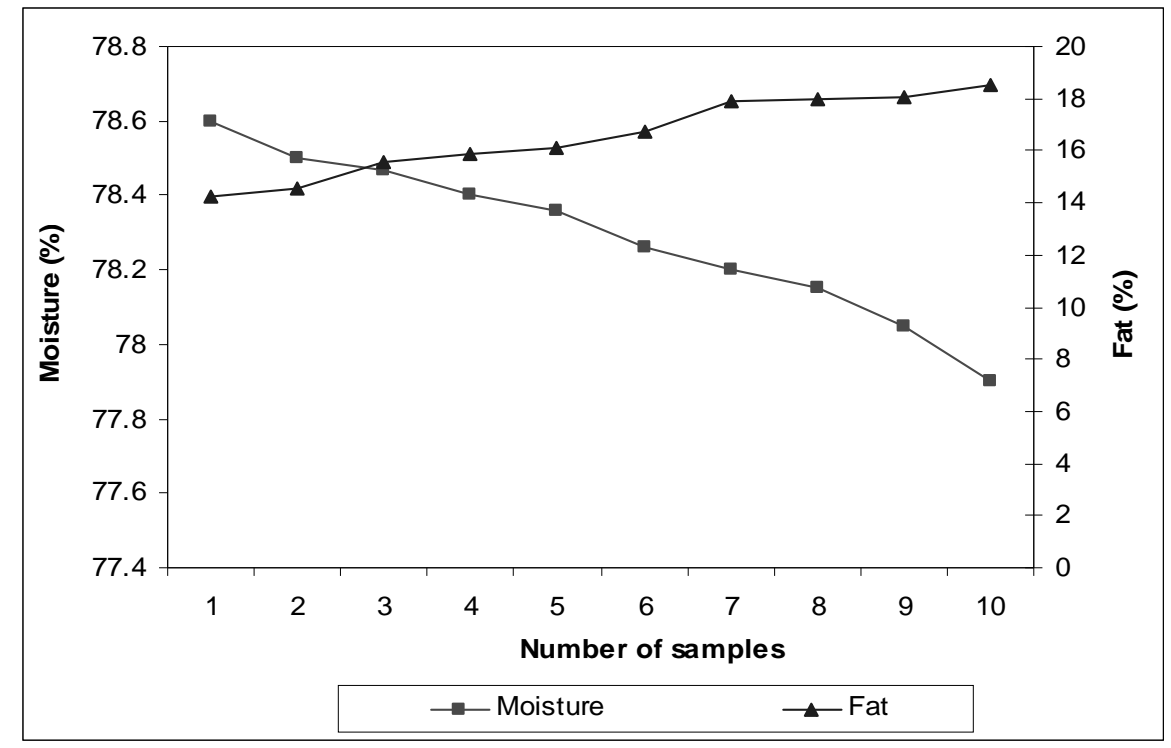

Fig. 2. Inverse relationship found between Moisture (\%) and Fat (\%).

According to Stansby (1954) and Salam et al. (1995), variation in proximate composition of fish flesh may vary with species variation, season, age and feeding habit of the fish. Generally moisture content shows inverse relationship with lipid content also found in the Pungus fish (Fig. 2). The inverse relationship has also been reported in marine fishes such as Mugil cephalus (Das, 1978); Sarda sarda (Zaboukas, 2006) and freshwater fishes Mystus seenghala (Jafri, 1968) and Ophicephalus punctatus (Jafri and Khawaja, 1968). Jacquot (1961) in his experiment found that fatty fish contained $68.6 \%$ moisture, semi fatty fish contained $77.2 \%$ and lean fish contained $81.8 \%$ moisture which showed the inverse relationship between fat and moisture content. Therefore, this fish can play a significant role to fulfill the nutrient demand of the people in Bangladesh.

\section{References}

Abdullahi, S.A.; Abolude, D.S. and Ega, R.A. 2001. Nutrient quality of four oven dried freshwater catfish species in Northern Nigeria. J. Tropical Biosciences, 1(1): 70-76. 
Abimbola, A.O.; Kolade, O.Y. Ibrahim, A.O. Oramadike, C.E. and Ozor, P.A. 2010. Proximate and Anatomical Weight Composition of Wild Brackish Tilapia guineensis and Tilapia melanotheron, Journal of Food Safety, Vol.12, Nigerian Institute for Oceanography and Marine Research, Victoria Island, Lagos, pp. 100-103.

Axelrod, H. R. 1996. Exotic Tropical Fishes. T.F.H. Publications. ISBN 0-87666-543-1.

AOAC (Association of Official Analytical Chemicals). 1975. Official Method of Analysis. Association of Official Analytical Chemist, $12^{\text {th }}$ edition. Washington D.C.

Bligh, E.G and Dyer, W. 1959. Total Lipid Extraction and Purification. Can, J. Biochem. Physiol.37:99$110 \mathrm{p}$.

Chakwu, O. and Shaba, I.M. 2009. Effect of drying method on proximate composition of cat fish (Clarias gariepinus). Journal of World Agricultural Sciences, 5(1), 114-116.

Das, H. P. 1978. Studies on the Grey Mullet, Mugil cephalus (Linnaeus) from the Goa waters. $\mathrm{PhD}$ Thesis Submitted To University of Bombay, $223 \mathrm{p}$.

David, A. 1962. Brief taxonomic account of the Gangetic Pangasius pangasius (Ham.) with description of a new sub-species from the Godavari. Proc. Indian Acad. Sci. 34(3), 136-156.

Devadsan, K.; Varma, P. H. G. \& Ventatraman, R. 1978. Studies on Frozen Storage Characteristics of Fillets from Six Species of Freshwater Fish. Fish Technology, India pp. 1-6.

DoF (Department of Fisheries). 2009 Saranica, Matsya Pakhya Sankalan, Ministry of Fisheries and Livestock. The Government of Peoples republic of Bangladesh, Dhaka, 120p.

Food and Agriculture Organization (FAO). 1999. World production of fish, crustaceans and mollusks by major fishing areas. Fisheries Information and Data and Statistics Unit. (FIDI), Fisheries Department, FAO, Rome.33p.

Gheyasuddin, S.; Rahman, M.A. and Kamal, M. 1979. Nutritive Qualities of Some of the Commercial Marine Fishes of Bangladesh. Journal of Bangladesh Agriculture 4(1), 34-38.

Hussain, M. G. and Mazid, M. A. 2001. Genetic improvement and conservation of carp species in Bangladesh. Bangladesh Fisheries Research Institute and International Center for Living Aquatic Resources Management.

Jacquot, R. 1961. Organic Constituents of Fish and Other Aquatic Animal Foods. Fish as Food. Vol 1, Academic Press, Newyork.

Jafri, A. K. 1968. Seasonal changes in the biochemical composition of the freshwater cat fish, Wallagonia attu (Bloch.). Hydrobiologia, 33: 497-506.

Jafri, A. K. and Khawaja, D.K. 1968. Seasonal changes in the biochemical composition of the freshwater murrel, Opiiicephalus punctatus, Bloch. Hydrobiologia, 32: 206-218.

Marias, J. F. K. and Erasmus, T. 1977. Body composition of Mugil cephalus, Liza dumerili, Liza richardsoni and Liza tricuspidens (Teleostei: Mugilidae) caught in the Swartkops estuary. Aquaculture. 10(1), 75-86.

Mazumder, M.S.A.; Rahman, M.M., Ahmed, A.T.A., Begum, M. and Hossain, M.A. 2008. Proximate Composition of Some Small Indigenous Fish Species (SIS) in Bangladesh, Journal of Int. sustain. Crop pord. 3(4), 18-23.

Mridha, M.A.; Lipi, S.Y., Narejo, N.T., Uddin, M.S., Kabir, M.S. and Karim, M. 2005. Determination of Biochemical Composition of Cirrhinus reba (Hamilton, 1822) from Jessore, Bangladesh, Journal of Science \& Technology University Peshawar 29(1), 1-5.

Nabi, R.M. and Hossain, M.A. 1989. Seasonal Variation In the Chemical Composition and Caloric Content of Macrognathus acuelatus (Bloch) from the Chalan Beel Water, Journal of Asiatic society Bangladesh 16(1), 61-66.

Nowsad, A. K. M. 2007. Participatory Training of Trainers, Bangladesh Fisheries Research Forum, Mymensingh, Bangladesh.

Osibona, A. O.; Kusemiju, K. \& Akande, G.R. 2006. Proximate Composition and Fatty Acids Profile of the African Catfish Clarias gariepinus, Journal of Life and Physical Science 3(1) 1-5.

Pearson, D. 1999. Pearson's Composition and analysis of foods. University of Reading.

Qudrat-I-Khuda, M.; De, H.N., Khan, N.H. and Debnath, J. C. 1962. Biochemical and nutritional studies on Pakistan Fish. Part 7. Chemical Composition and Quality of the Traditionally Processed Fish, Pakistan J., pp. 71-72.

Rahman, A. K. A. 1997. Fish marketing in Bangladesh. In: Tsai, C.F. and M.Y. Ali (eds.) Open Water Fisheries of Bangladesh, BCAS/University Press Limited.

Roberts, T. R., Vidhayanon, C (1991). Systematic revision of the Asian catfish family Pangasiidae, with biological observation and descriptions of three new species. Proc. Acad. Nat. Sci. Philad. $143,97-144$.

Saha, K.C. \& Guha, B.C. 1939. Nutritional Investigation of Bengal Fish, India, pp. 921-927. 
Salam, M.A., Alam, N., Nasiruddin, M., Nabi, R. and Howlader, M.Z.H. 1995. Biochemical composition of body muscles and its caloric contents of tawes (Puntius gonionotius, Bleeder). Journal of Bangladesh Sci. Res., 13(2), 205-211.

Stansby, M. E. 1962. Composition of certain species of freshwater fish. Food. Res.19:231-234.
Stansby, M. E. 1985. Fish or Fish oil in the diet and heart attack. Mar. Fish. Review, 46(2): 60-63.

Zaboukas, N., Miliou, H., Megalofonou, P., and Lou, M. M. A. 2006. Biochemicale composition of the Atlantic bonito Sarda sarda from the Aegean Sea (Eastern Mediterranean Sea) in different stages of sexual maturity. Journal of Fish Biology 69, 347-362. 